\title{
PIÈCE DE RÉSISTANCE
}

\author{
Dena Davida
}

\section{PIÈCE DE RÉSISTANCE: un exposé de la femme musclee}

"Femme Musclée:" ce qu'il n'y a pas si longtemps, était encore considéré comme une attraction de cirque, est devenue une réalité. Des mythiques Amazones à l'élection de Miss Olympia, rien, ou presque, dans l'histoire ne vient déranger l'ordre musculaire établi. Mais voilà que des représentantes du sexe faible (?), filles de Wonder Woman adeptes du body-building et de l'aerobic, viennent occuper un terrain jusque là exclusif aux proéminences des culturistes mâles. La "femme musclée" provoque de houleux débats. Intolérance ou simple inaccoutumance? Jusqu'à quel point une femme peutelle se muscler? Y a-t-il un style féminin musclé? La taille doit-elle être toujours étroite, les hanches larges? Par un mélange d'improvisation-contact, d'acrobaties, de poses culturistes, de sensualité féline et de pur effort physique, Dena Davida et Louise Parent exposent le sujet. Un montage visuel d'Ormsby Ford et sonore de Debbie Danbrook et la participation de la culturiste Paula Dosne, viendront illustrer le rapport encore paradoxal, féminité/effort pliysique.

They tensed for all they were worth, clenching their fists and showing to an assembled group of people ... rippled, delineated, vein-splayed muscle, in their thighs, their shoulders, their stomachs and their chests, all the historically soft and comforting areas of a woman. (Gaines and Butler, "Iron Sisters," Psychology Today, Nov. 1983)

A dance to 1985: from Amazonia to Ms. Olympia. An interface of femininity and strength. The anima / animus (Yin/Yang) balance. Daughters of Wonder Woman and Jane Fonda's fitness programs. An archetype with little history. The controversy clearly stated by the host at Place des Arts' 1984 Ms. Olympia women's bodybuilding competition, "This is not a beauty contest, these women are serious athletes." 
Consider the body as architecture. Your skeletal girders a strong-delicate supporting system of bridges, pulleys, levers, pivots. Each bony curve and jointure designed to accommodate the weight spring upwards and gravitational pull downwards. (Dena Davida, Reflections of a Post-Post Modern Dancer)

Dance in the eighties, inheritors of Judson Church, searching for contemporary sources for gesture and meaning. A post-Cunningham/Cage acceptance of all ways of structuring dance. The fusing and inter-breeding of mediums. PIÈCEDERÉSISTANCE proposes an athletic blend of Contact Improvisation, acrobatics, bodybuilding posing, feline sensuality and sheer physical effort. Precise movement phrases dissolve into frenzied improvisation. Muscularity is examined not only as pure body sculpture, but also in effortful action - supporting, lifting, controlling, resisting and letting go into exhaustion. Here is a fusion of Louise Parent and Dena Davida's commitment to personal style. Both have been seriously strength-training since September 1984.

... the history of art is practically as barren of truly muscular women as it is of, say, men with breasts. The shape to which the female body tends to return (has been) most often suggested by what Sir Kenneth Clark calls "an oval surrounded by two spheres." (Gaines and Butler)

An unabridged history of muscular women: Mythical Amazonia. Spartan female athletes in 1400 BC. Skip to 1890 vaudeville's sensational queens of strength Athleta, Vulcana and Sandwina. Then in 1900 women were finally admitted to the Olympic games. Finally wait again until 1979 and Lisa Lyons. That's it.

Pictures of muscular women provoke heated debate. The modern eye is still unaccustomed. How much is too much? What are the limits? Is there a feminine style? Must her waist be small, hips wide always? How should she move? PIÈCE DE RÉSISTANCE exposes the subject, incites the questions. As one advertiser of chrome dumbbells headlines: "Woman: a new definition." 
Pièce de Résistance · 95

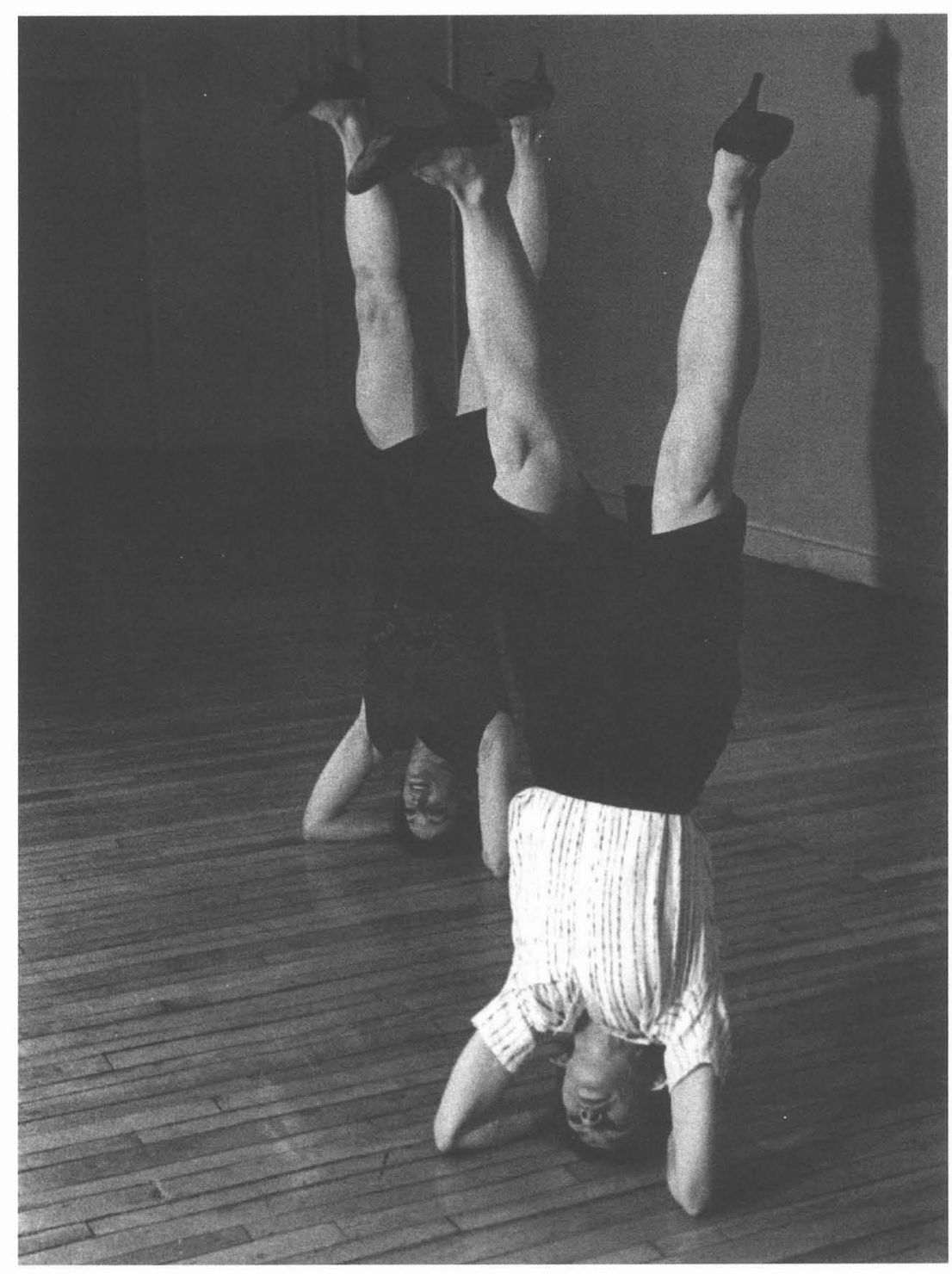

photo: Ormsby Ford 
$96 \cdot$ Tessern

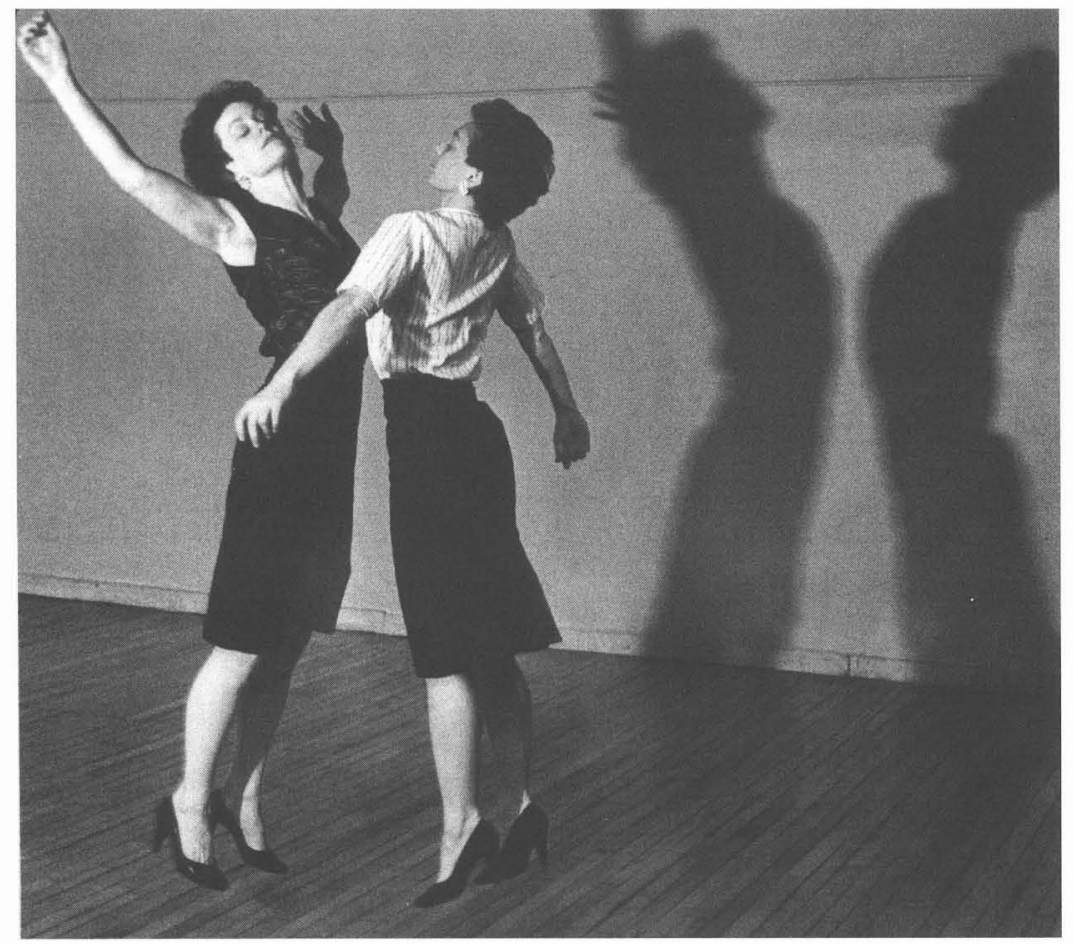

photo: Ormsby Ford 
Pièce de Résistance · 97

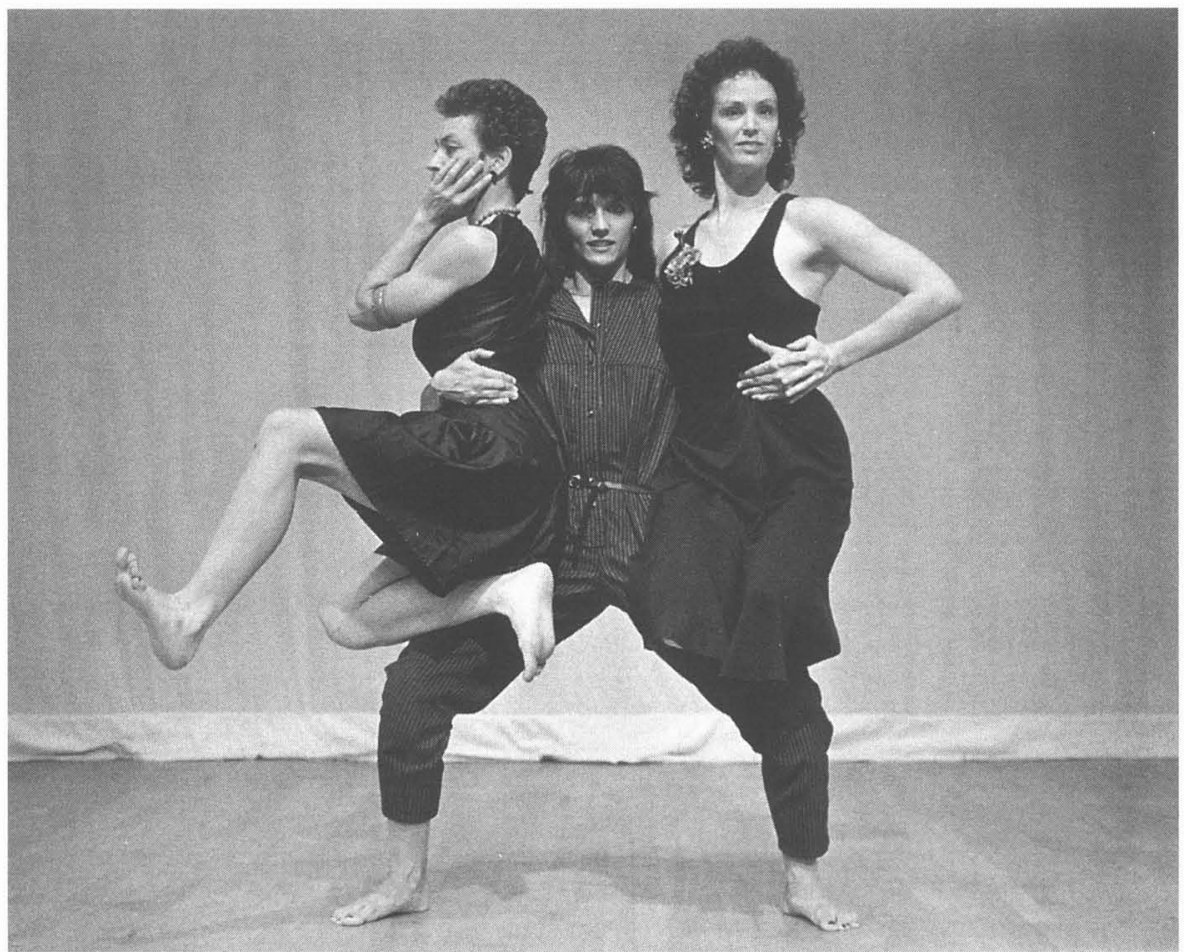

photo: Donna Marie Marchand 
98. Tessera

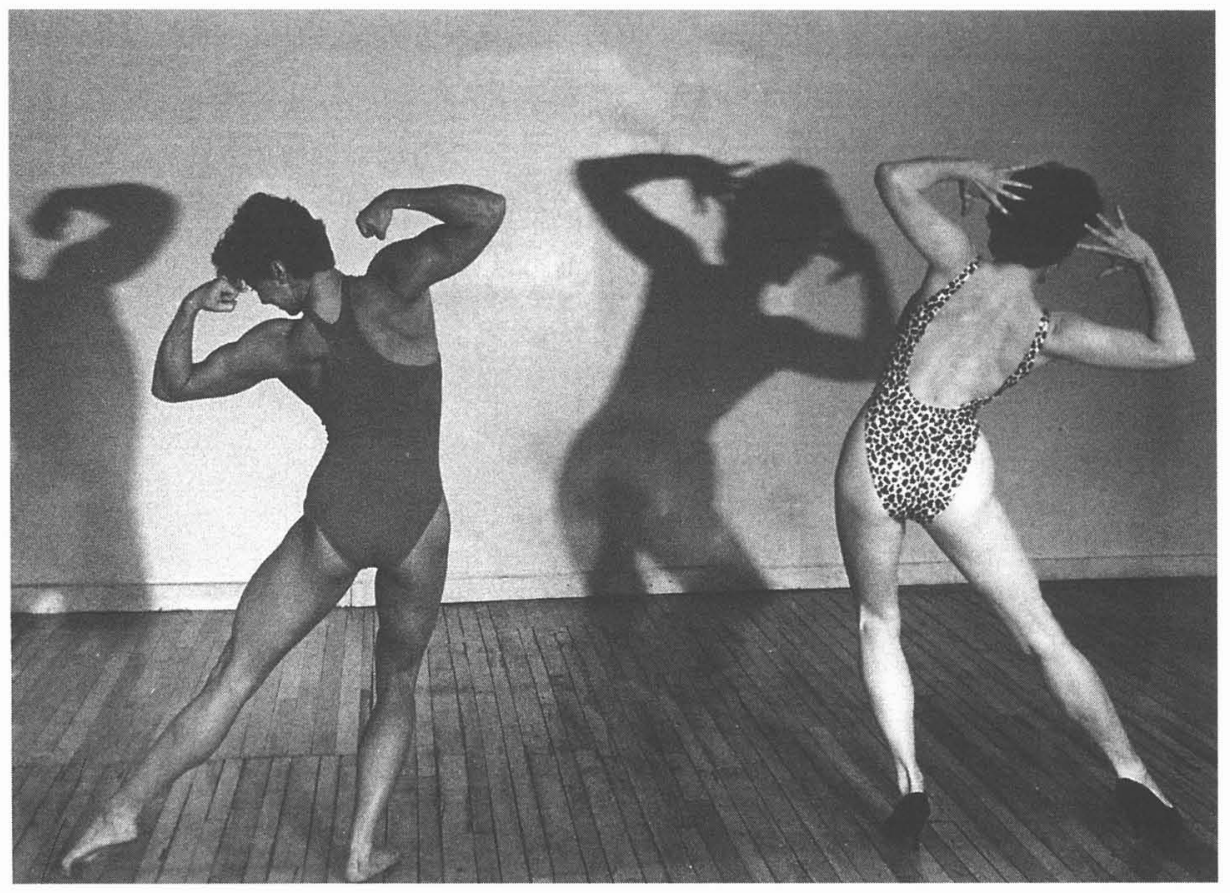

photo: Ormsby Ford 